\title{
Angiotensin II Induces Plasminogen Activator Inhibitor-1 and -2 Expression in Vascular Endothelial and Smooth Muscle Cells
}

\author{
Edward P. Feener, Jill M. Northrup, Lloyd Paul Aiello, ${ }^{\star}$ and George L. King \\ Research Division, and *Beetham Eye Institute, Joslin Diabetes Center, Harvard Medical School, Department of Medicine, \\ Brigham and Women's Hospital, Boston, Massachusetts 02215
}

\begin{abstract}
Angiotensin II (AII) - and Arg ${ }^{8}$-vasopressin (AVP)-regulated gene expression in vascular cells has been reported to contribute to vascular homeostasis and hypertrophy. In this report, AVP-induced expression of plasminogen activator inhibitor (PAI)-2 mRNA in rat microvessel endothelial ( RME) cells was identified using differential mRNA display. Further characterization of vasoactive peptide effects on PAI expression revealed that AII stimulated a 44.8 $\pm 25.2-$ fold and a 12.4 \pm 3.2-fold increase in PAI-2 mRNA in RME cells and rat aortic smooth muscle cells (RASMC), respectively. AII also stimulated a 10- and 48-fold increase in PAI1 mRNA in RME cells and RASMC, respectively. These AII effects were inhibited by either Sar ${ }^{1}$, Ile $^{8}$-angiotensin or the $\mathrm{AT}_{1}$ antagonist DuP 735, but were not significantly altered in the presence of the $\mathrm{AT}_{2}$ antagonist PD123319. AII stimulation of RASMC and RME cells also significantly increased both PAI-1 protein and PAI activity released to the culture medium. Inhibition of protein kinase $C$ completely blocked PMA-stimulated induction of PAI-2 mRNA in both cell types and inhibited the AII-stimulated increase in RASMC by $98.6 \pm 2.8 \%$. In contrast, protein kinase $C$ inhibition only partially decreased the AII-stimulated PAI-2 expression in RME cells by $68.8 \pm 11.1 \%$, suggesting that a protein kinase $\mathrm{C}$-independent mechanism contributes to a $6.9 \pm 1.5$-fold AII induction of PAI-2 expression in endothelial cells. AII and PMA also stimulated protein tyrosine phosphorylation in RME cells, and the tyrosine kinase inhibitor genistein partially blocked their induction of PAI-2 mRNA. These findings suggest that AII may regulate plasminogen activation in the vasculature by inducing both PAI-1 and PAI-2 expression. (J. Clin. Invest. 1995. 95:1353-1362) Key words: angiotensin II • plasminogen activator inhibitor • endothelial cell • vascular smooth muscle cells $\cdot$ gene expression
\end{abstract}

Address correspondence to Edward P. Feener, Ph.D., Research Division, Joslin Diabetes Center, One Joslin Place, Boston, MA 02215.

Received for publication 17 May 1994 and in revised form 27 September 1994.

1. Abbreviations used in this paper: AII, angiotensin II; ACE, angiotensin-converting enzyme; AVP, $\mathrm{Arg}^{8}$-vasopressin; PAI, plasminogen activator inhibitor; PKC, protein kinase C; RASMC, rat aortic smooth muscle cells; RME, rat microvessel endothelial; RT, reverse transcription; tPA, tissue plasminogen activator; uPA, urokinase plasminogen activator

J. Clin. Invest.

(C) The American Society for Clinical Investigation, Inc.

$0021-9738 / 95 / 03 / 1353 / 10 \quad \$ 2.00$

Volume 95, March 1995, 1353-1362

\section{Introduction}

Angiotensin II (AII) ${ }^{\prime}$ is a vasoactive peptide that exerts a variety of effects on vascular cells and tissues. AII regulates vascular tone both by its direct vasopressor effects on contractile cells, such as vascular smooth muscle cells, and via the induction of other vasoactive compounds in endothelial cells, such as endothelin- 1 and prostaglandins $(1,2)$. In addition, AII exerts effects on the vasculature that are independent of the regulation of vascular tone. AII stimulation of both mitogenesis and protein synthesis in vascular smooth muscle cells has been reported to contribute to vascular hypertrophy (3-5). AII has also been shown to stimulate c-myc, c-fos, platelet-derived growth factor, basic fibroblast growth factor, insulin-like growth factor-I, and tissue factor expression in vascular smooth muscle cells (610). These reports suggest that AII-regulated gene expression in vascular cells may mediate a diverse array of actions of the angiotensin system in the vasculature.

Growing experimental and clinical evidence strongly suggests that the renin-angiotensin system contributes to the pathogenesis of a number of vascular diseases. Recent genetic studies have linked an angiotensinogen gene allele to the occurrence of essential hypertension $(11,12)$. Polymorphisms in the angiotensin-converting enzyme ( ACE) gene have been linked to leftventricular hypertrophy, cardiomyopathy, myocardial infarction, and diabetic nephropathy (13-17). Inhibition of the proteolytic conversion of angiotensin I to AII with ACE inhibitors, an established therapy for hypertensive and congestive heart failure $(18,19)$, has also been shown to reduce intimal thickening following vascular injury, myocardial infarction, and the progression of diabetic nephropathy (20-23). Interestingly, the results of several of these studies have demonstrated that the beneficial effects of ACE inhibition occur via a mechanism that is, in part, independent of its antihypertensive actions.

Several reports have also suggested that the renin-angiotensin system may regulate plasminogen activation and fibrinolysis. Studies by Bell et al. have demonstrated that ACE inhibition increases urokinase plasminogen activator ( $\mathrm{PPA}$ ) expression in cultured aortic endothelial cells $(24,25)$. The systemic infusion of AII has been reported to increase circulating levels of plasminogen activator inhibitor (PAI)-1 (26). In addition, clinical studies have shown that ACE inhibition reduces the rate of recurrent myocardial infarction in patients with left-ventricular dysfunction $(21,22)$. While these studies suggest that AII may inhibit fibrinolysis in the vasculature, the role of AII on plasminogen activator inhibitor expression in vascular cells has not been reported.

While examining vasoactive hormone-regulated gene expression using differential mRNA display (27-29), a PCRbased screening technique, we found that $\operatorname{Arg}^{8}$-vasopressin (AVP) induced plasminogen activator inhibitor-2 (PAI-2) ex- 
pression in cultured rat microvessel endothelial (RME) cells. Further studies revealed that AII was also a potent stimulator of PAI-2 mRNA expression. In this report, we examined and compared the effect of AII on PAI-1 and PAI-2 expression in RME cells and rat aortic smooth muscle cells (RASMC). The possibility that AII stimulation of these vascular cells may regulate plasminogen activation was investigated by examining the effect of AII on the release of PAI-1 protein and PAI activity from these cells. In addition, the AII receptor isoform and signal transduction mechanisms involved in the AII-induced expression of PAI-1 and PAI-2 in these vascular cells were investigated. These studies suggest that AII stimulation of plasminogen activator inhibitor expression in vascular endothelial and smooth muscle cells may lead to impaired plasminogen activation in both the micro- and macrovasculature.

\section{Methods}

Cell culture. RME cells were isolated from epididymal fat pads as described previously (30). Cells were cultured on fibronectin-coated plates in Dulbecco's minimum essential medium (DMEM) containing $100 \mathrm{mg} / \mathrm{dl}$ glucose (Gibco Laboratories, Grand Island, NY) and $10 \%$ ( vol/vol) plasma-derived horse serum (Lampire Biological Laboratories, Piperville, PA). RME cells from passage 9 to 16 were used in these studies. RASMC were isolated from Sprague-Dawley rats as described previously (31), cultured in DMEM containing $10 \%$ fetal calf serum, and used between passages 7 and 10 . Confluent monolayers of cells were serum deprived in DMEM containing $0.1 \%$ (wt/vol) BSA for $18 \mathrm{~h}$ before stimulation. Cells were stimulated with AII, AVP, or PMA (Sigma Chemical Co., St. Louis, MO). For AII receptor antagonist studies, cells were pretreated for $15 \mathrm{~min}$ with $\mathrm{Sar}^{1}, \mathrm{Ile}^{8}$-angiotensin (Sigma Chemical Co.), DuP 735 (provided by Dr. Ronald D. Smith, DuPont Merck Pharmaceutical Co., Wilmington, DE), or PD123319 (provided by Dr. David G. Taylor, Parke Davis, Morris Plains, NJ), followed by stimulation with $100 \mathrm{nM}$ AII. The roles of protein kinase $\mathrm{C}$ (PKC) and tyrosine phosphorylation were examined in cells pretreated for 15 min with $10 \mu \mathrm{M}$ GF $109203 \mathrm{X}$ (Calbiochem-Novabiochem Corp., La Jolla, CA), or $6 \mu \mathrm{g} / \mathrm{ml}$ genistein (LC Laboratories, Woburn, MA) followed by stimulation with either $100 \mathrm{nM}$ AII or $160 \mathrm{nM}$ PMA.

RNA isolation and Northern blot analysis. Total RNA was isolated using UltraSpec ${ }^{\text {TM }}$ RNA (Biotecx, Houston, TX). 10-20 $\mu \mathrm{g}$ of total RNA was separated in a $1 \%(\mathrm{wt} / \mathrm{vol})$-agarose gel containing $20 \mathrm{mM}$ Mops, pH 7.0, $5 \mathrm{mM} \mathrm{NaOAc,} 1 \mathrm{mM}$ EDTA, $0.76 \mu \mathrm{g} / \mathrm{ml}$ ethidium bromide, and $0.67 \%$ formaldehyde. RNA was transferred by capillary technique to Biotrans ${ }^{\mathrm{TM}}$ membrane (ICN Pharmaceuticals, Inc., Irvine, CA), and ultraviolet cross-linked. Agarose gel-purified cDNA probes for PAI-1 and PAI-2 were labeled with a DNA labeling system (Multiprime, Amersham Corp., Arlington Heights, IL), and purified by gel filtration using Nap-5 columns (Pharmacia LKB Biotechnology Inc., Piscataway, NJ). Blots were hybridized in $50 \mathrm{mM}$ Pipes, $100 \mathrm{mM}$ $\mathrm{NaCl}, 50 \mathrm{mM} \mathrm{NaPO}, 1$ mM EDTA, $0.1 \%$ salmon sperm DNA (Sigma Chemical Co.), and $5 \%$ SDS at $65^{\circ} \mathrm{C}$. The blots were then washed with $0.5 \mathrm{X} \mathrm{SSC}$ and $5 \%$ SDS at $65^{\circ} \mathrm{C}$ and visualized by a PhosphorImager (Molecular Dynamics, Inc., Sunnyvale, CA).

Isolation of PAI-1 and PAI-2 cDNA probes by reverse transcription (RT)-PCR and differential mRNA display. AVP-regulated gene expression in RME cells was examined by differential mRNA display (27), with modifications described previously $(28,29)$. A differentially expressed PCR product was generated with primers AGGGAACGAG and $\mathrm{GVT}_{12}$ (V was degenerate for G, A, and C). This PCR fragment was subcloned using the TA Cloning ${ }^{\mathrm{TM}}$ system (Invitrogen, San Diego, CA) and sequenced using the Sequenase Version 2.0 kit (United States Biochemical Corporation, Cleveland, $\mathrm{OH}$ ) with primers to the Sp6 and T7 promoters (Gibco BRL, Gaithersburg, MD). The cloned 250 bp PCR insert was released from the TA vector by digestion with EcoRI, sepa- rated in a 1.5\% agarose gel, eluted from the agarose, and labeled for use in Northern blot analysis.

A cDNA probe for rat PAI-1 was generated by RT-PCR of RNA from PMA-stimulated RASMC using oligonucleotide primers ATAGAATTCCACGAGTACGACATCCTGGAACTGC and ATAGGATCCCCCTCTGAGG-TCCACTTCAGTCTCC (Midland Bio Products Corp., Boone, IA) to the rat PAI-1 coding sequence (32). RT was performed on $0.2 \mu \mathrm{g}$ RNA in the presence of $1 \mathrm{mM}$ antisense primer,

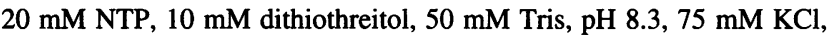
$3 \mathrm{mM} \mathrm{MgCl}_{2}$, and $10 \mathrm{U}$ Superscript RT (Gibco BRL) for $1 \mathrm{~h}$ at $37^{\circ} \mathrm{C}$. The PCR reaction mixture included $1.0 \mathrm{mM}$ of the primers, $10 \% \mathrm{RT}$ mix, $10 \mathrm{mM}$ Tris, $\mathrm{pH} 8.3,50 \mathrm{mM} \mathrm{KCl}, 3 \mathrm{mM} \mathrm{MgCl}, 0.001 \%$ gelatin, $2.0 \mathrm{mM}$ NTP, and $0.05 \mathrm{U} / \mu \mathrm{l}$ Amplitaq (Perkin-Elmer Cetus, Norwalk, CT). The PCR conditions were $94^{\circ} \mathrm{C} \times 30 \mathrm{~s}, 59^{\circ} \mathrm{C} \times 2 \mathrm{~min}, 72^{\circ} \mathrm{C} \times$ $30 \mathrm{~s}$, for 40 cycles. The agarose gel-purified PCR product was cloned into Bluescript KS (Stratagene Inc., La Jolla, CA) using the EcoRI or BamHI restriction sequences that were included in the $5^{\prime}$ ends of the primers.

Analysis of PAI-1 levels and PAI activity in conditioned medium. RME cells and RASMC were cultured in six-well plates (Costar Corp., Cambridge, MA). Confluent monolayers of cells were washed with PBS and incubated in $1 \mathrm{ml} /$ well DMEM without phenol red (Gibco BRL) for $30 \mathrm{~h}$. During this incubation cells were treated with $100 \mathrm{nM}$ AII for $0,1,2,4,6$, or $24 \mathrm{~h}$. Medium from triplicate wells was pooled and centrifuged at $1,000 \mathrm{~g}$ for $5 \mathrm{~min}$. The monolayers were washed on ice with PBS and scraped from the wells with $250 \mu \mathrm{l}$ lysis buffer (50 $\mathrm{mM}$ Tris, $\mathrm{pH} 7.5,150 \mathrm{mM} \mathrm{NaCl}, 1 \%$ (vol/vol) Triton X-100, $2 \mathrm{mM}$ phenylmethylsulfonyl fluoride, and $0.1 \mathrm{mg} / \mathrm{ml}$ aprotinin). The triplicate wells were pooled and insoluble material was removed by centrifugation at $14,000 \mathrm{~g}$ for $5 \mathrm{~min}$. The supernatants from the cell lysate and medium were stored at $-80^{\circ} \mathrm{C}$. Protein concentrations from the cell lysates were determined by the Bradford method using a protein assay (Bio-Rad Laboratories, Richmond, CA). For PAI-1 immunoblotting, $100 \mu \mathrm{g}$ of BSA was added to $1 \mathrm{ml}$ of medium and the mixture was precipitated with $10 \%(\mathrm{vol} / \mathrm{vol})$ trichloroacetic acid for $30 \mathrm{~min}$ on ice. Samples were centrifuged at $14,000 \mathrm{~g}$ for $5 \mathrm{~min}$, and pellets were washed three times with $500 \mu \mathrm{l}$ diethyl ether, dissolved in $150 \mu \mathrm{l}$ Laemmli sample buffer containing $2 \%(\mathrm{vol} / \mathrm{vol})$ 2-mercaptoethanol, and boiled for 3 min. Samples ( $75 \mu 1$ ) were separated by SDS-PAGE ( $10 \%$ acrylamide), transferred to nitrocellulose (Schleicher \& Schuell, Inc., Keene, NH), and immunoblotted with $5 \mu \mathrm{g} / \mathrm{ml}$ rabbit anti-rat PAI-1 (American Diagnostica, Inc., Greenwich, CT) followed by $0.2 \mu \mathrm{Ci} / \mathrm{ml}{ }^{125}{ }^{12}$-labeled protein A (Amersham Corp.) in $25 \mathrm{mM}$ Tris, $\mathrm{pH} 7.5,150 \mathrm{mM} \mathrm{NaCl}$, and $5 \%$ (wt/vol) nonfat dry milk. Results were visualized and quantitated by PhosphorImage analysis (Molecular Dynamics, Inc.). Molecular weights were estimated using prestained low molecular weight markers (Bio-Rad Laboratories). Data were normalized to protein concentrations of cell lysates.

PAI activity in the conditioned media was measured using the Spectrolyse ${ }^{\otimes}$ tissue plasminogen activator (tPA)/PAI kit (American Diagnostica, Inc.). Briefly, conditioned media were preincubated with a tPA standard and the remaining free tPA activity was measured in a reaction mixture containing plasminogen, fibrin, and a chromogenic substrate (D-Val-Leu-Lys-para-nitroaniline) for plasmin.

Immunoblot analysis of protein tyrosine phosphorylation. Confluent 10-cm dishes of RME cells were serum deprived for $18 \mathrm{~h}$ in DMEM $+0.1 \% \mathrm{BSA}$, then stimulated for $3 \mathrm{~min}$ with $100 \mathrm{nM} \mathrm{AVP}$ or AII or with $160 \mathrm{nM}$ PMA. Cells were washed two times with ice-cold PBS containing $2 \mathrm{mM} \mathrm{Na}_{2} \mathrm{VO}_{4}$, scraped from the dish, and centrifuged for $5 \mathrm{~min}$ at $500 \mathrm{~g}$ at $4^{\circ} \mathrm{C}$. Cell pellets were lysed in $50 \mathrm{mM}$ Tris, $\mathrm{pH} 7.4$, $2 \mathrm{mM}$ EGTA, $10 \mathrm{mM}$ EDTA, $100 \mathrm{mM} \mathrm{NaF}, 1 \mathrm{mM} \mathrm{Na}_{2} \mathrm{P}_{2} \mathrm{O}_{7}, 1 \%$ Triton $\mathrm{X}-100,2 \mathrm{mM} \mathrm{NaVO}{ }_{4}, 2 \mathrm{mM}$ phenylmethylsulfonyl fluoride, $0.2 \mathrm{mg} /$ $\mathrm{ml}$ aprotinin for $30 \mathrm{~min}$ on ice. Samples were then centrifuged at 17,000 $g$ for $5 \mathrm{~min}$. $50 \mu \mathrm{g}$ of protein from each cell extract (supernatant) was boiled in Laemmli sample buffer, separated by $7.5 \%$ SDS-PAGE, and transferred to nitrocellulose. The nitrocellulose was incubated in

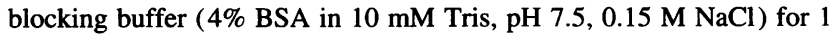


$\mathrm{h}$ and then incubated for $1 \mathrm{~h}$ with $20 \mu \mathrm{g} / \mathrm{ml}$ polyclonal antiphosphotyrosine antibody (Upstate Biotechnology, Inc., Lake Placid, NY) diluted in blocking buffer for $1 \mathrm{~h}$. The nitrocellulose was then washed $5 \times 5$ min in $10 \mathrm{mM}$ Tris, $\mathrm{pH} 7.5,0.15 \mathrm{M} \mathrm{NaCl}$, incubated with $0.2 \mu \mathrm{Ci} / \mathrm{ml}$ ${ }^{125}$ I-protein A (Amersham Corp.) for $1 \mathrm{~h}$, and washed $4 \times 20 \mathrm{~min}$. Molecular weights were estimated by comparison with high molecular weight markers (Bio-Rad Laboratories).

Data analysis. Quantitation of PAI-1 and PAI-2 mRNA levels and PAI-1 protein levels was performed by PhosphorImage analysis (Molecular Dynamics, Inc.) PAI-1 and PAI-2 mRNA levels were normalized to 36B4 mRNA, a constitutively regulated mRNA $(27-29,33)$, as indicated. Significant changes in PAI mRNA, protein, and activity levels from control and stimulated cells were determined by the Student's $t$ test. Values of $P<0.05$ were considered statistically significant.

\section{Results}

Isolation of cDNA probes against rat PAI-1 and PAI-2 by RT$P C R$ and differential mRNA display. Differential mRNA display was used to examine vasoactive hormone-regulated gene expression in cultured RME cells. As a result of this analysis, a PCR product that was present in the RT-PCR reactions from cells stimulated for $2 \mathrm{~h}$ with $100 \mathrm{nM}$ AVP but was absent in reactions from the unstimulated control was identified. This PCR fragment was cloned, and its sequence matched the cDNA for plasminogen activator inhibitor-2 type A (PAI-2) from Rattus norvegicus $\left(P=3.4 \times 10^{-61}\right)$. The primers used in this PCR reaction hybridized to the coding sequence of PAI-2 at 1,113 to 1,119 bp and a poly-A-rich region between 1,350 and $1,360 \mathrm{bp}$ (sequence data are available from EMBL/GenBank/ DDBJ under accession number X64563), resulting in a 250-bp PCR fragment. Northern blot analysis with this cloned PCR product revealed that this PAI-2 probe hybridized to a $2.2-\mathrm{kb}$ mRNA, which was increased 23-fold $(n=3)$ in AVP-treated RME cells (data not shown). A cDNA probe for rat PAI-1 was also generated by the RT-PCR of mRNA from PMA-stimulated RASMC using oligonucleotides to the rat PAI-1 sequence reported in GenBank. This cloned PCR product contained $198 \mathrm{bp}$ of coding sequence that was identical to PAI-1 cDNA (32). In this report, we have used these cDNA probes against PAI-1 and PAI-2 to examine the role of AII in the regulation of PAI expression in RME cells and RASMC.

Comparison of AII-stimulated PAI-1 and PAI-2 mRNA expression in vascular endothelial and smooth muscle cells. The kinetics of the AII effect on PAI-1 and PAI-2 expression was examined by Northern blot analysis of total RNA from control and AII-stimulated RASMC and RME cells (Fig. 1, $A$ and $B$ ). The basal expression of PAI- 2 mRNA in the unstimulated control RASMC or RME cells was low and occasionally not detected in 15-20 $\mu \mathrm{g}$ total RNA. Stimulation of cells with 100 nM AII rapidly increased PAI-2 mRNA, reaching a peak at 2 and $4 \mathrm{~h}$ in RME cells and RASMC, respectively (Fig. 1, $A$ and $B$ ). A cDNA probe to acidic ribosomal phosphoprotein PO (36B4, a constitutively expressed mRNA [33]) was used to compare RNA loading. Analysis of PAI-1 expression revealed that a basal level of PAI-1 mRNA could be detected in the unstimulated control cells. An increase in PAI-1 expression was observed after $1 \mathrm{~h}$ of AII stimulation, and PAI-1 mRNA expression reached a maximum after $4 \mathrm{~h}$ (Fig. 1, $A$ and $B$ ).

While both cell types expressed PAI-1 and PAI-2, RME cells and RASMC differed in the relative expression of these inhibitors. These differences were quantitated by Northern blot

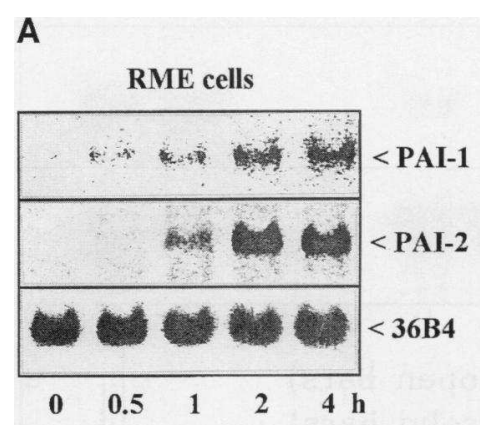

B

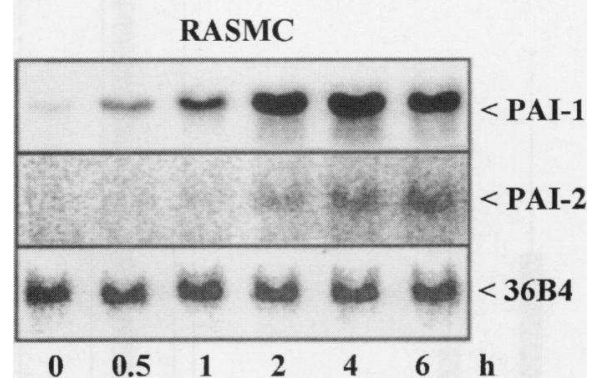

Figure 1. Time course of AII-stimulated PAI-1 and PAI-2 mRNA expression in RME cells and RASMC. RNA was isolated from RME cells $(A)$ and RASMC $(B)$ that were stimulated with $100 \mathrm{nM}$ AII at $37^{\circ} \mathrm{C}$ for the times indicated. Northern blot analysis was performed with $\left[\alpha^{32} \mathrm{P}\right]$ ATP-labeled cDNA probes for PAI-1 and PAI-2. The cDNA probe to $36 \mathrm{~B} 4$, which hybridizes to acidic ribosomal phosphoprotein PO, was used to compare RNA loading. Results were visualized using a PhosphorImager (Molecular Dynamics, Inc.). Data shown are representative blots from three experiments.

analysis of RNA isolated from control and AII-stimulated RME cells and RASMC in the same experiment. This analysis revealed that AII-stimulated PAI-1 expression was significantly greater $(P<0.05)$ in RASMC than in RME cells (Fig. 2, $A$ and $C$ ). In contrast, PAI-2 expression was consistently greater in RME cells than in RASMC (Fig. 2, $B$ and $C$ ). This difference in PAI-2 expression, however, was not statistically significant. The effects of PMA on PAI-1 and PAI- 2 mRNA expression were also compared in these two cell types. Previous reports have demonstrated that phorbol ester stimulates the expression of PAI-2 in a number of other cell types (34-36). This analysis revealed that the PMA-stimulated expression of PAI-2 was 33.3 \pm 16.0 ( $\mathrm{SEM}, n=5$ ) in RME cells and 81.8 \pm 16.4 (SEM, $n=4)$ in RASMC. Thus, while the effects of AII and PMA on the levels of PAI-2 mRNA were comparable in RME cells, the AII effect was significantly less than the PMA effect in RASMC $(P<0.5)$.

Dose response of AII indicated that significant increases in both PAI-1 and PAI-2 mRNA levels were observed at $1 \mathrm{nM}$ AII $(P<0.05)$, and a maximal effect was observed at $100 \mathrm{nM}$ AII (Fig. 3). Pretreatment of the cells with $1 \mu \mathrm{M}$ of the AII receptor antagonist $\mathrm{Sar}^{1}$, $\mathrm{Ile}^{8}$-angiotensin inhibited the AIIstimulated expression of PAI-2 in RME cells (Fig. 3). A similar dose response of AII on PAI-1 and PAI-2 expression was observed in RASMC (data not shown).

Role of the $A T_{1}$ and $A T_{2}$ receptors in the AII-stimulated induction of PAI-1 and PAI-2 expression in RME cells and 


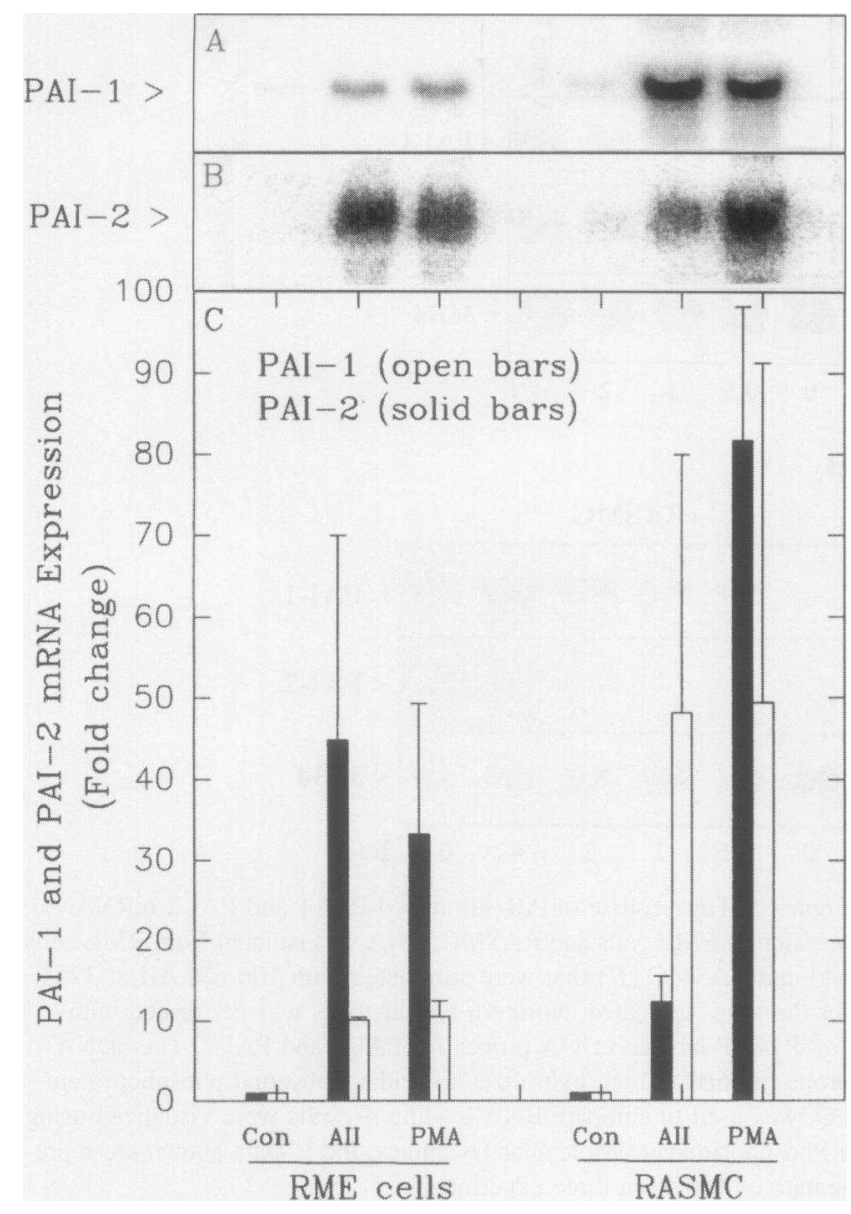

Figure 2. Comparison of AII-stimulated PAI-1 and PAI-2 mRNA expression in RME cells and RASMC. Cultured vascular cells were stimulated with $100 \mathrm{nM}$ AII or $160 \mathrm{nM}$ PMA at $37^{\circ} \mathrm{C}$ for $2 \mathrm{~h}$ (RME cells) or $4 \mathrm{~h}$ (RASMC). Northern blot analysis was performed using ${ }^{32} \mathrm{P}$ labeled PAI-1 or PAI-2 cDNA probe on $15 \mu \mathrm{g} /$ lane of total RNA from RME cells $(A)$ and $20 \mu \mathrm{g} /$ lane RNA from RASMC $(B)$. Results were visualized and quantitated by PhosphorImager (Molecular Dynamics, Inc.) and are representative of at least three separate experiments. Maximal AII- and PMA-stimulated expression of PAI-1 (open bars) and PAI-2 (solid bars) at $2 \mathrm{~h}$ in RME cells and $4 \mathrm{~h}$ in RASMC was expressed as the fold increase (mean \pm SEM, $n=3-6$ ) compared to mRNA levels in the unstimulated cells in $C$.

RASMC. The role of AII receptor isoforms (reviewed in reference 37) were examined with the $\mathrm{AT}_{1}$ antagonist DuP 753 and $\mathrm{AT}_{2}$ antagonist PD123319. Cells were pretreated with $30 \mathrm{nM}$ to $1 \mu \mathrm{M}$ of these antagonists for $15 \mathrm{~min}$ and then stimulated with $100 \mathrm{nM}$ AII as described in Fig. 2. Northern blot analysis of RNA from these cells revealed that DuP 735 was significantly more effective than PD123319 in inhibiting AII stimulation of both PAI-1 and PAI-2 mRNA expression in both cell types. The $\mathrm{AT}_{2}$ antagonist PD123319 did not significantly block AIIinduced PAI- 1 and PAI-2 expression in either cell type. AIIstimulated PAI-2 expression was significantly inhibited by 100 $\mathrm{nM}$ and higher concentrations of DuP 735 (Fig. 4, $A$ and $B$ ). At $1 \mu \mathrm{M}$ DuP 735 the AII-stimulated levels of PAI- 2 mRNA were decreased by $91.2 \pm 0.8 \%( \pm$ SEM, $n=3$ ) in RME cells and $98.4 \pm 2.5 \%$ ( \pm SEM, $n=3$ ) in RASMC. AII-stimulated PAI-1 expression was also significantly inhibited at $300 \mathrm{nM}$

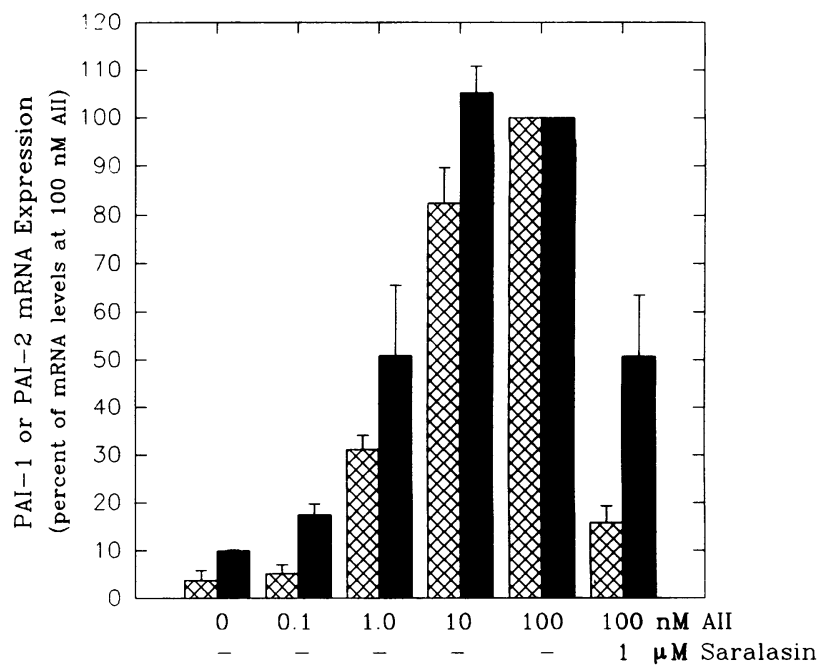

Figure 3. Dose response and effect of saralasin on AII-stimulated PAI1 and PAI-2 mRNA expression. RME cells were stimulated for $2 \mathrm{~h}$ with the indicated concentrations of AII in the absence or presence of $1 \mu \mathrm{M}$ saralasin. RNA was isolated from these cells, and PAI-1 (solid bars) and PAI-2 (hatched bars) mRNA expression was examined by Northern blot analysis against $10 \mu \mathrm{g} /$ lane of total RNA. Results were quantitated by PhosphorImage (Molecular Dynamics, Inc.) and expressed as a percentage of the mRNA levels observed in the presence of $100 \mathrm{nM}$ AII. Data are presented as the mean \pm SEM for three experiments. AII significantly increased PAI- 1 and PAI-2 mRNA at concentrations of $1 \mathrm{nM}$ and higher $(P<0.05)$.

and $1 \mu \mathrm{M}$ DuP 753; however, PAI-1 mRNA levels were only reduced by $34.1 \pm 6.5$ to $50.1 \pm 14.1 \%( \pm \mathrm{SEM}, n=3)$ at $1 \mu \mathrm{M}$ DuP 735 (Fig. 4, $C$ and $D$ ).

Analysis of AII-stimulated PAI-1 protein and PAI activity released from RASMC and RME cells. The effect of AII stimulation on the PAI-1 levels in the conditioned culture medium from RASMC and RME cells was examined to determine if the increase in PAI-1 mRNA correlated to an elevated level of PAI1 release from these cells. Conditioned medium was collected from cells after a $30-\mathrm{h}$ incubation that included up to a 24-h stimulation with $100 \mathrm{nM}$ AII. The medium was concentrated and PAI-1 levels were measured by immunoblot analysis. The molecular weight of PAI-1 from these cells was $52 \mathrm{kD}$, which agrees with previous reports (38). In the absence of AII-stimulation, RME cells did not release a detectable amount of PAI1 (Fig. 5 A). However, an increasing level of PAI-1 was observed in the culture medium from RME cells stimulated with AII for 4, 6, and $24 \mathrm{~h}$. For RASMC, PAI-1 was observed in the medium from control cells, and an increase in PAI- 1 was also observed after 6 and $24 \mathrm{~h}$ of AII stimulation. Fig. $5 B$ shows that the PAI-1 level in the medium from RASMC stimulated for $24 \mathrm{~h}$ with AII was significantly greater than that from the unstimulated control and from the AII-stimulated RME cell ( $P$ $<0.05)$.

The PAI activity in the culture medium from control and AII-stimulated cells was examined. PAI activity was measured in the conditioned medium from control cells and cells stimulated with AII for $24 \mathrm{~h}$. A significant level of PAI activity was not detected in the culture medium from control RME cells; however, the medium from AII-stimulated cells contained $3.90+0.14( \pm \mathrm{SD}, n=3)$ IU of PAI activity (Fig. 6). For 

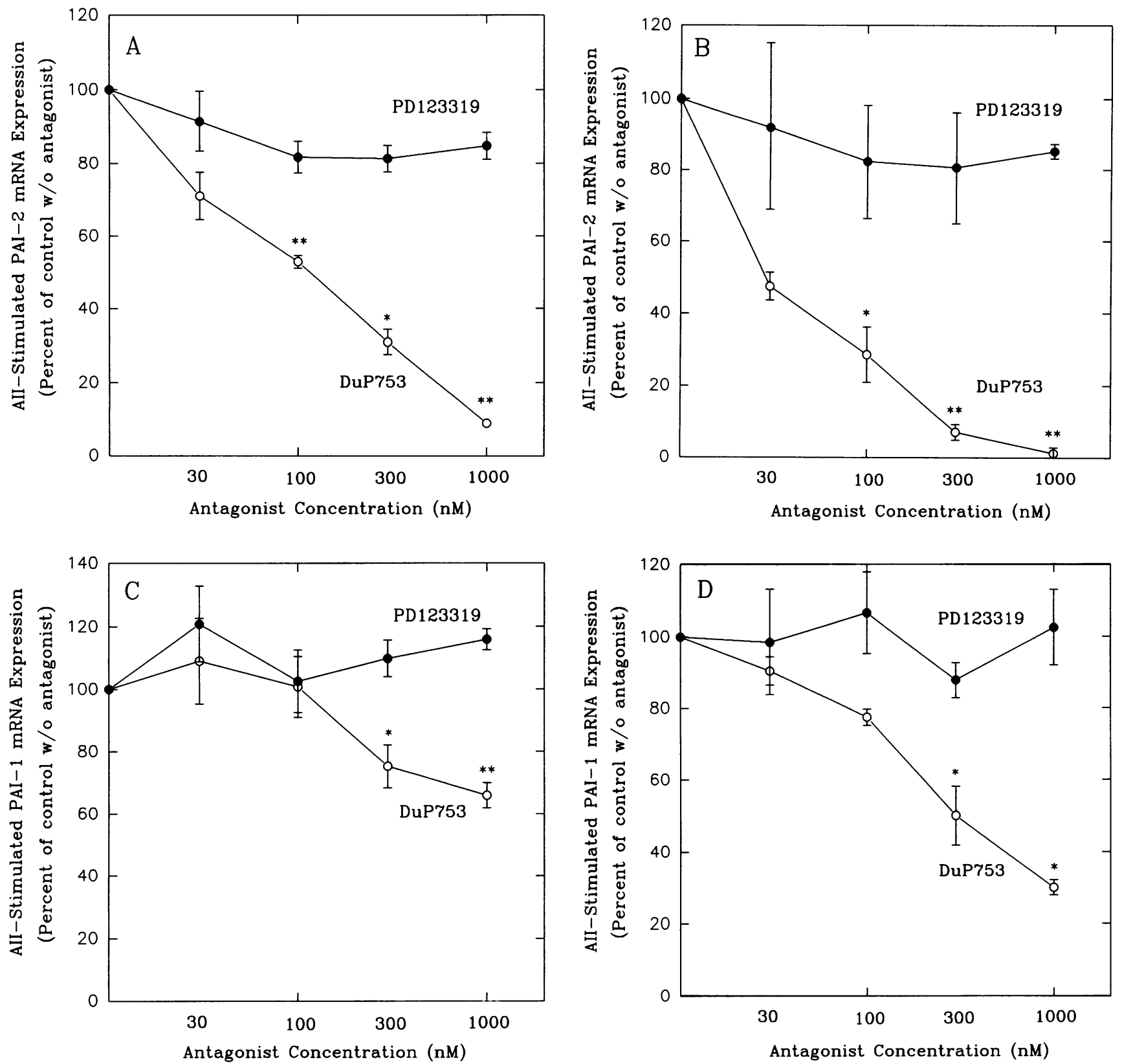

Figure 4. Effect of $\mathrm{AT}_{1}$ and $\mathrm{AT}_{2}$ antagonists on AII-induced PAI-1 and PAI-2 mRNA expression. RME cells $(A$ and $C)$ and RASMC $(B$ and $D)$ were pretreated with the indicated concentrations of DuP 735 and PD123319 for 15 min, and stimulated with $100 \mathrm{nM}$ AII for $2 \mathrm{~h}(A$ and $B$ ) or 4 $\mathrm{h}(C$ and $D$ ). PAI-2 ( $A$ and $B$ ) and PAI-1 ( $C$ and $D$ ) mRNA expression was determined by Northern blot analysis, and results from three experiments were quantitated using a PhosphorImager (Molecular Dynamics, Inc.) and normalized to 36B4 mRNA levels. Significant inhibition at the indicated concentrations of antagonist are indicated as $* * P<0.01$ and $* P<0.05$.

RASMC, AII stimulation significantly increased PAI activity in the culture medium from $1.86 \pm 0.53$ to $38.1 \pm 2.89 \mathrm{IU}$ (SD, $n=3, P<0.01)$. These PAI activity results are comparable with the immunoreactive PAI-1 levels shown in Fig. 5.

AII stimulation of PAI-2 expression requires both $P K C$ and tyrosine kinase activity. Previous studies have demonstrated that the activation of the $\mathrm{AT}_{1}$ receptor in vascular cells leads to the $G$ protein-mediated activation of phospholipase $\mathrm{C}$, increased levels of diacylglycerol, and the activation of PKC $(39,40)$. This AII-stimulated signaling mechanism has been shown to mediate the increase in endothelin-1 mRNA expression in macrovessel endothelial cells and cardiomyocytes $(1,41)$.

The signal transduction mechanism involved in the AIIstimulated increase in PAI-2 expression was investigated. The direct activation of PKC with PMA increased PAI-2 expression 33.3 \pm 16.0 - and 81.8 \pm 16.4 -fold in RME cells and RASMC, respectively. This is consistent with previous reports that have demonstrated that PKC increases the transcription of PAI- 2 via two AP1 binding sites located in the 5 ' flanking promoter region of the gene (35). The role of PKC in the AII stimulation of 

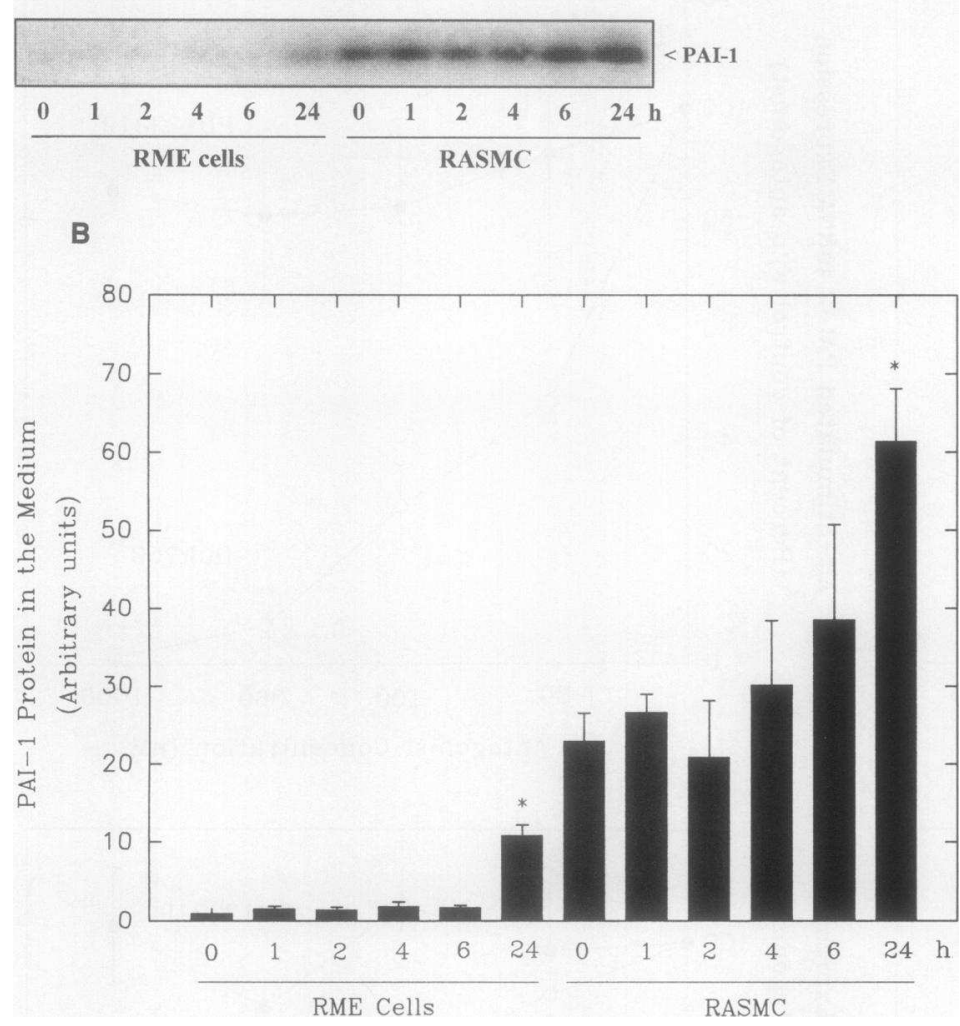

Figure 5. Immunoblot analysis of PAI-1 levels in the culture medium. RME cells and RASMC were incubated in DMEM without phenol red for $30 \mathrm{~h}$ and stimulated with $100 \mathrm{nM}$ AII for the times indicated. Conditioned medium was collected, concentrated by trichloroacetic acid precipitation, and separated by SDS-PAGE. PAI-1 was immunoblotted with a rabbit anti-rat PAI-1 polyclonal antibody followed by ${ }^{125} \mathrm{I}$-labeled protein A. A representative blot is shown in $A$. In $B$, data from three experiments were quantitated by PhosphorImager (Molecular Dynamics, Inc.), normalized to cellular protein, and expressed as (mean \pm SEM) of the fold change from the PAI-1 levels in the medium of unstimulated RME cells. Significant differences in PAI-1 levels from the control and AIIstimulated cultures were determined by the Student's $t$ test and indicated as $* P<0.05$.
PAI-2 was examined in cells treated with bisindolylmaleimide (GF 109203X), a staurosporine analogue and a highly selective inhibitor of PKC (42). Fig. 7, $A$ and $C$, shows that this PKC inhibitor could completely block the PMA-stimulated increase

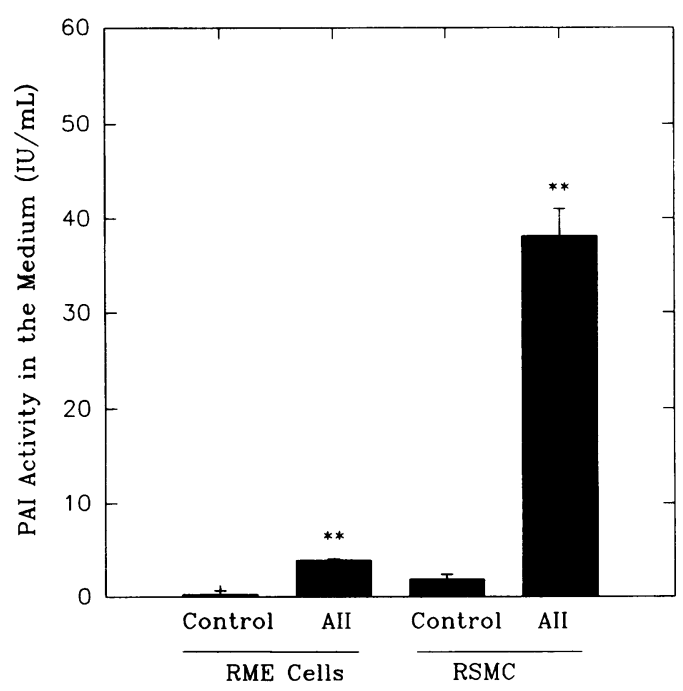

Figure 6. AII-stimulated plasminogen activator inhibitor levels in conditioned medium. Conditioned medium from control and AII-stimulated (24 h) RME cells and RASMC was generated as described in Fig. 5. PAI activity was determined by preincubating these media with a IPA standard and measuring tPA activity using a chromogenic substrate. Results are the mean \pm SD from three experiments. AII significantly increased PAI activity in both cell types. $* * P<0.01$. in PAI-2 (Fig. $7 A$, lanes $g$ and $h$ ), and significantly reduce the AII effect by $68.8 \pm 11.1 \%$ (Fig. $7 A$, lanes $b$ and $d$ ) in RME cells. The role of PKC in the AII stimulation of PAI- 2 was also examined in RME cells that were PKC-downregulated by prolonged pretreatment with PMA. Previously, we have shown that PKC protein and activity can be downregulated in endothelial cells after a preincubation with 800 nM PMA $(43,44)$. This downregulation of PKC decreased the AII-stimulated induction of PAI- 2 by $\sim 80 \%$ (data not shown), confirming that PKC is an important mediator of AII-stimulated PAI- 2 expression. However, the remaining 6.9 \pm 1.5 -fold AII stimulation of PAI-2 expression in GF 109203X-treated RME cells, where the PMA response is completely blocked (Fig. $7 \mathrm{C}$ ), indicates that a PKC-independent pathway contributes to the AII stimulation of PAI-2 in these cells. In contrast, the effect of AII on PAI2 expression in RASMC was completely blocked (98.6 $\pm 2.8 \%$ inhibition) by the inhibition of PKC with GF 109203X (Fig. $7, B$ and $C$ ), and this inhibition was significantly greater than that observed in RME cells $(P<0.05)$.

Several reports have demonstrated that AII can increase protein tyrosine phosphorylation in glomerular mesangial cells and smooth muscle cells $(45,46)$. We examined the effects of AII, AVP, and PMA on tyrosine phosphorylation in RME cells. Cells were serum starved for $18 \mathrm{~h}$ and then stimulated with 100 nM AII or $160 \mathrm{nM}$ PMA for $3 \mathrm{~min}$. The cells were lysed in the presence of protease and phosphatase inhibitors. Proteins were separated by SDS-PAGE, and tyrosine phosphorylation was visualized by immunoblot analysis with polyclonal antiphosphotyrosine antibody. Fig. 8 shows that AII and PMA stimulated the tyrosine phosphorylation of several proteins, with apparent molecular weights of $\sim 120,110$, and $70-80 \mathrm{kD}$. A similar 
A

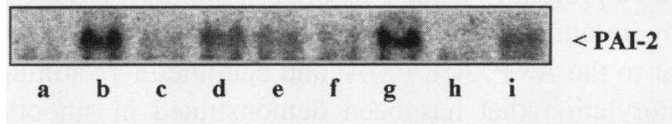

B

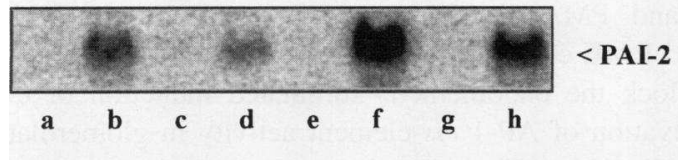

C

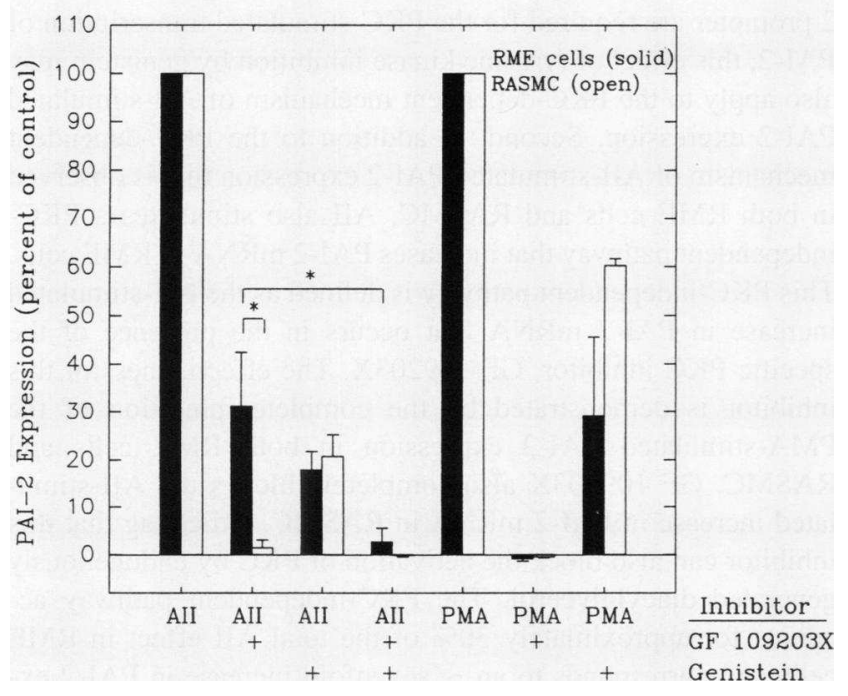

Figure 7. Effect of PKC and tyrosine kinase inhibition on AII- and PMA-stimulated PAI-2 expression in RMC cells and RASMC. Northern blot analysis with ${ }^{32} \mathrm{P}$-labeled PAI-2 probe (37G3A) was performed on: (A) $10 \mu \mathrm{g}$ RNA from RME cells stimulated for $2 \mathrm{~h}$ as follows: $(a)$ unstimulated control, (b) $100 \mathrm{nM}$ AII, (c) $100 \mathrm{nM}$ AII $+1 \mu \mathrm{M} \mathrm{Sar}{ }^{1}$, Ile ${ }^{8}$-angiotensin, (d) $100 \mathrm{nM} \mathrm{AII}+10 \mu \mathrm{M}$ GF $109203 \mathrm{X},(e) 100 \mathrm{nM}$ AII $+6 \mu \mathrm{g} / \mathrm{ml}$ genistein, $(f) 100 \mathrm{nM}$ AII + GF 109203X + genistein, (g) 160 nM PMA, $(h) 160$ nM PMA $+10 \mu$ M GF 109203X, and $(i)$ $160 \mathrm{nM}$ PMA $+6 \mu \mathrm{g} / \mathrm{ml}$ genistein, or $(B) 20 \mu \mathrm{g}$ RNA from RASMC (a) incubated for $4 \mathrm{~h}$ in DMEM $+0.1 \%$ BSA alone or in the presence of (b) $100 \mathrm{nM}$ AII, (c) AII $+10 \mu \mathrm{M}$ GF 109203X, (d) AII $+6 \mu \mathrm{g} /$ ml genistein, $(e)$ AII + GF109203 + genistein, $(f) 160$ nM PMA, $(g)$ PMA + GF109203X, $(h)$ PMA + genistein. Results were visualized and quantitated with a PhosphorImager (Molecular Dynamics, Inc.). The blots shown are representative from three similar experiments. $(C)$ PAI-2 mRNA levels from both RME cells and RASMC were normalized to 36B4 and expressed as a percentage of AII- or PMA-stimulated PAI2 expression in the absence of inhibitors, mean $\pm \operatorname{SD}(n=3)$. Significant differences are indicated as $*(P<0.05)$.

pattern of AII-, AVP-, and PMA-stimulated protein tyrosine phosphorylation was observed with RASMC (data not shown).

The role of tyrosine phosphorylation in both the PKC-dependent and -independent induction of PAI-2 mRNA was examined in cells pretreated with genistein, a specific tyrosine kinase inhibitor (47). Genistein decreased both AII- and PMA-stimulated PAI-2 expression in RME cells by $82.1 \pm 3.9 \%$ and $70.9 \pm 16.4 \%$, respectively (Fig. $7 C$ ). Genistein also inhibited the AII- and PMA-stimulated increase in PAI-2 mRNA in RASMC (Fig. $7 C$ ). Treatment of RME cells with both GF

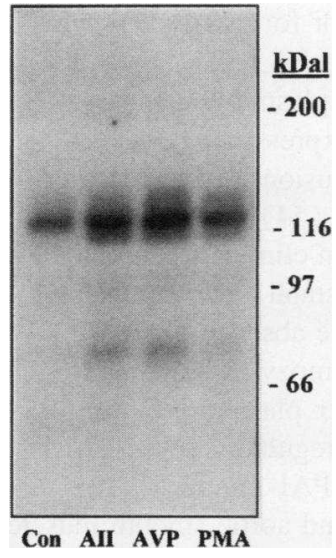

Figure 8. AII-, AVP-, and PMA-stimulated protein tyrosine phosphorylation in RME cells. RME cells were incubated in culture medium containing $0.1 \% \mathrm{BSA}$ for $18 \mathrm{~h}$ and then stimulated for $3 \mathrm{~min}$ with either $100 \mathrm{nM}$ AII, 100 nM AVP, or 160 nM PMA. Cells were washed and lysed in a buffer containing protease and phosphatase inhibitors, and protein was separated by SDSPAGE. Immunoblot analysis was performed with antiphosphotyrosine antibody and ${ }^{125} \mathrm{I}$-labeled protein A. Results were visualized by autoradiography. The blot shown is representative of four independent experiments.

109203X and genistein inhibited the AII stimulation of PAI-2 expression by $97.3 \pm 2.8 \%$ (Fig. $7 C$ ), and the level of PAI-2 mRNA in the presence of both of these inhibitors was not significantly different than the level of the unstimulated control. The $0.1 \%$ ( vol/vol ) dimethylsulfoxide carrier used to solubilize these inhibitors did not significantly after PAI-2 expression (not shown). These results suggest that tyrosine phosphorylation may contribute to both the PKC-dependent and -independent mechanisms of AII-stimulated PAI-2 mRNA expression in RME cells. Similar results were obtained from mechanistic studies of the AII-stimulated expression of PAI-1 mRNA in vascular cells (data not shown).

\section{Discussion}

In this report, we have demonstrated that AII is a potent stimulator of PAI-1 and PAI-2 expression in cultured vascular endothelial and smooth muscle cells. The AII-induced increases in PAI1 and PAI-2 mRNA levels were both rapid and of striking magnitude. Comparison of these results to previous reports on the hormone-regulated expression of PAI-1 mRNA in vascular cells (48-50) suggests that AII is among the most potent stimulators of plasminogen activator inhibitor expression in vascular endothelial and smooth muscle cells. Dose response studies demonstrated that a significant induction of PAI-1 and PAI-2 mRNA levels were observed at a physiological concentration of AII ( $1 \mathrm{nM})$, and its maximal effect at between 10 and 100 $\mathrm{nM}$ was similar to or lower than other AII actions that have been reported $(1,3,6,7,40)$. The maximal AII stimulation of PAI-1 and PAI-2 mRNA expression at $100 \mathrm{nM}$ AII was inhibited with DuP 735, demonstrating that the $\mathrm{AT}_{1}$ receptor isoform mediated these increases. Since the renin-angiotensin system may generate high local concentrations of AII due to its autocrine/paracrine production (51), the induction of PAI-1 and PAI-2 in endothelial and smooth muscle cells was studied at the maximal AII stimulation. The kinetics and relative magnitudes of the AII-induced expression of PAI-1 mRNA in these vascular cells corresponded to increases in PAI-1 protein and PAI activity released to the medium. Interestingly, the AIIstimulated expression of PAI-1 mRNA was consistently greater in vascular smooth muscle cells than in endothelial cells, while the reverse was true of AII stimulation of PAI- 2 mRNA expression. These results suggest that the AII stimulation of these cells may differentially regulate plasminogen activation. 
PAI-1 and PAI-2 are the two major forms of plasminogen inactivators that inhibit both tPA and UPA (52). PAI- 1 is the major plasminogen inactivator in the plasma and the primary inhibitor of tPA $(52,53)$. Overexpression of PAI-1 in transgenic mice increased venous occlusions, resulting in ischemia and necrosis in the digits and tail (54). Recent studies on mice in which the PAI-1 gene has been eliminated by homologous recombination demonstrated a small but significant increase in fibrinolytic activity (55). The absence of a severe or lethal increase in fibrinolysis in the homozygous mice with the "PAI-1 knockout" suggests that other plasminogen inactivators, such as PAI-2, are also important regulators of fibrinolysis. Since AII is a potent stimulator of both PAI- 1 and PAI-2 expression in microvessel endothelial cells and aortic smooth muscle cells, these results suggest that AII action in micro- and macrovasculature may impair fibrinolysis and possibly contribute to thrombus formation.

While PAI-2 can also inhibit tPA and fibrinolysis, it preferentially inactivates uPA and is primarily associated with cell surface receptors and with the extracellular matrix (52). The role of uPA is primarily the regulation of extracellular matrix turnover involved in cell migration and tissue remodeling (52). Since PAI-2 is a rapid and irreversible inhibitor of UPA (38), the AII-stimulated increase in PAI-2 expression in the endothelium would be expected to impair extracellular matrix proteolysis and cell migration. This is consistent with previous studies, which have shown that ACE inhibitor treatment of vascular endothelial cells increased uPA levels and activity, and this increase in uPA activity correlated with an increase in endothelial cell migration $(24,25)$. Thus the induction of uPA by ACE inhibition and the stimulation of PAI- 2 by AII suggests that the angiotensin system can reduce plasminogen activation in vascular endothelial cells via at least two mechanisms. In contrast, AII stimulates both uPA levels (24) and PAI-2 expression in aortic smooth muscle cells. The AII-stimulated increases in both UPA and PAI-2 may suggest that the level of UPA activity in vascular smooth muscle is regulated by the autocrine production of PAI-2. Moreover, these results demonstrate that there are significant differences in both AII signaling and AII regulation of the PAI system in vascular endothelial and smooth muscle cells.

The demonstration that AII increases PAI-1 and PAI-2 expression in vascular cells may suggest that the renin-angiotensin system regulates PAI expression in the vasculature. This hypothesis would be consistent with studies that have shown that AII infusion in control subjects increases PAI-1 levels in the plasma (26), and that ACE inhibitors reduce recurrent myocardial infarction in patients with left-ventricular dysfunction $(21,22)$. Further studies are necessary to determine if treatment with ACE inhibitors alters the expression of the plasminogen system and the regulation of fibrinolysis in the vasculature.

Analysis of the signal transduction pathway involved in the regulation of PAI-2 in vascular cells indicated that a PKCdependent mechanism mediated most or all of the AII-stimulated PAI-2 expression in RME cells and RASMC, respectively. This was expected since the vascular AII receptor $\left(\mathrm{AT}_{1}\right)$ has been shown to be coupled to the hydrolysis of phosphoinositol and the activation of PKC $(39,40)$. However, further analysis and comparison of the AII-stimulated expression of PAI-2 in these vascular cells revealed two novel results. First, the AIIand PMA-stimulated expression of PAI-2 requires tyrosine phosphorylation in both RME cells and RASMC. AII- and PMA-stimulated protein tyrosine phosphorylation in RME cells was shown by immunoblot analysis. This tyrosine phosphorylation is similar to the AVP, AII, PMA, and endothelin-1-stimulated phosphorylation that has been demonstrated in smooth muscle cells and in glomerular mesangial cells $(45,46,56)$. The tyrosine kinase inhibitor genistein significantly decreased both AII- and PMA-stimulated PAI-2 expression in both RASMC and RME cells. Tyrosine kinase inhibitors have been shown to block the endothelin-1-stimulated induction of cfos and activation of AP-1 cis-element activity in glomerular mesangial cells (51). Since Cousins et al. (35) have shown that two AP-1 binding sites in the 5' flanking region of the PAI2 promoter are required for the $\mathrm{PKC}$-stimulated transcription of PAI-2, this effect of tyrosine kinase inhibition by genistein may also apply to the PKC-dependent mechanism of AII-stimulated PAI-2 expression. Second, in addition to the PKC-dependent mechanism of AII-stimulated PAI-2 expression that is observed in both RME cells and RASMC, AII also stimulates a PKCindependent pathway that increases PAI- 2 mRNA in RME cells. This PKC-independent pathway is defined as the AII-stimulated increase in PAI-2 mRNA that occurs in the presence of the specific PKC inhibitor, GF 109203X. The effectiveness of this inhibitor is demonstrated by the complete inhibition of the PMA-stimulated PAI-2 expression in both RME cells and RASMC. GF 109203X also completely blocks the AII-stimulated increase in PAI-2 mRNA in RASMC, indicating that this inhibitor can also block the activation of PKC by endogenously generated diacylglycerol. The PKC-independent pathway accounts for approximately $30 \%$ of the total AII effect in RME cells and corresponds to an $\sim$ sevenfold increase in PAI- 2 expression. The inhibition of the PKC-independent pathway by genistein suggests that this pathway also involves tyrosine phosphorylation. This PKC-independent pathway in RME cells may contribute to the greater effectiveness of AII in the stimulation of PAI-2 mRNA in RME cells compared to RASMC.

In summary, we have shown that AII is a potent stimulator of PAI-1 and PAI-2 mRNA expression in both vascular endothelial and smooth muscle cells. The AII-stimulated expression of PAI-1 is greater in smooth muscle cells, and the expression of PAI-2 is greater in endothelial cells. The increases in PAI1 mRNA correlate with increased levels of PAI-1 protein and PAI activity released to the medium. These AII effects in the vascular cells are mediated via the $\mathrm{AT}_{1}$ receptor. Studies of the mechanism of AII stimulation of PAI-2 expression in these two vascular cell types demonstrated a role for both PKC and a protein tyrosine kinase, and, in addition, revealed the presence of a PKC-independent pathway in endothelial cells. Thus the stimulation of PAI-1 and PAI-2 expression by AII may have important physiological significance to the vascular complications associated with hypertension and the treatment of vascular diseases with ACE inhibitors.

\section{Acknowledgments}

The authors would like to thank Dr. R. D. Smith for providing DuP 735 and Dr. D. G. Taylor for providing PD123319. Excellent technical assistance was provided by Jennifer Gagne.

Support for this study was provided by National Institutes of Health grant DK-23811-06 (G. L. King), the Mary K. Iacocca Fellowship (E. P. Feener), Juvenile Diabetes Foundation Research Award (E. P. 
Feener), the Heed Fellowship Foundation (L. P. Aiello), and Diabetes Endocrinology and Research Center grant DK 36836, Joslin Diabetes Center.

\section{References}

1. Imai, T., Y. Hirata, T. Emori, M. Yanagisawa, T. Masaki, and F. Marumo. 1992. Induction of endothelin-1 gene by angiotensin and vasopressin in endothelial cells. Hypertension (Dallas). 19:753-757.

2. Jaiswal, N., D. I. Diz, M. C. Chappell, M. C. Khosla, and C. M. Ferrario. 1992. Stimulation of endothelial cell prostaglandin production by angiotensin peptides. Characterization of receptors. Hypertension (Dallas). 19(Suppl. II):II49-II-55.

3. Ko, Y., H. Stiebler, G. Nickenig, A. J. Wieczorek, H. Vetter, and A. Sachinidis. 1993. Synergistic action of angiotensin II, insulin-like growth factor$\mathrm{I}$, and transforming growth factor- $\beta$ on platelet-derived growth factor-BB, basic fibroblast growth factor, and epidermal growth factor-induced DNA synthesis in vascular smooth muscle cells. Am. J. Hypertens. 6:496-499.

4. Berk, B. C., V. Vekshtein, H. M. Gordon, and T. Tsuda. 1989. Angiotensin II-stimulated protein synthesis in cultured vascular smooth muscle cells. Hypertension (Dallas). 13:305-314.

5. Morishita, R., J. Higaki, M. Miyazaki, and T. Ogihara. 1992. Possible role of the vascular renin-angiotensin system in hypertension and vascular hypertrophy. Hypertension (Dallas). 19:II-62-II-67. (Suppl. II)

6. Naftilan, A. J., R. E. Pratt, and V. J. Dzau. 1989. Induction of plateletderived growth factor A-chain and $c$-myc gene expression by angiotensin II in cultured rat vascular smooth muscle cells. J. Clin. Invest. 83:1419-1424.

7. Taubman, M. B., B. C. Berk, S. Izumo, T. Tsuda, R. W. Alexander, and B. Nadal-Ginard. 1989. Angiotensin II induced c-fos mRNA in aortic smooth muscle. J. Biol. Chem. 264:526-530.

8. Delafontaine, P., and H. Lou. 1993. Angiotensin II regulates insulin-like growth factor I gene expression in vascular smooth muscle cells. J. Biol. Chem. 268:16866-16870.

9. Itoh, H., M. Mukoyama, R. E. Pratt, G. H. Gibbons, and V. J. Dzau. 1993. Multiple autocrine growth factors modulate vascular smooth muscle cell growth response to angiotensin II. J. Clin. Invest. 91:2268-2274.

10. Taubman, M. B., J. D. Marmur, C.-L. Rosenfield, A. Guha, S. Nichtberger, and Y. Nemerson. 1993. Agonist-mediated tissue factor expression in cultured vascular smooth muscle cells. J. Clin. Invest. 91:547-552.

11. Jeunemaitre, X., F. Soubrier, Y. V. Kotelevtsev, R. P. Lifton, C. S. Williams, A. Charru, S. C. Hunt, P. N. Hopkins, R. R. Williams, J.-M. Lalouel, and P. Corvol. 1992. Molecular basis of human hypertension: role of angiotensinogen. Cell. 71:169-180.

12. Caulfield, M., P. Lavender, M. Farrall, P. Munroe, M. Lawson, P. Turner, and A. J. L. Clark. 1994. Linkage of the angiotensinogen gene to essential hypertension. N. Engl. J. Med. 330:1629-1633.

13. Schunkert, H., H.-W. Hense, S. R. Holmer, M. Stender, S. Perz, U. Keil, B. H. Lorell, and G. A. J. Riegger. 1994. Association between a deletion polymorphism of the angiotensin-converting-enzyme gene and left ventricular hypertrophy. N. Engl. J. Med. 330:1634-1638.

14. Raynolds, M. V., M. R. Bristow, E. W. Bush, W. T. Abraham, B. D. Lowes, L. S. Zisman, C. S. Taft, and M. B. Rerryman. 1993. Angiotensin-converting enzyme DD genotype in patients with ischaemic or idiopathic dilated cardiomyopathy. Lancet. 342:1073-1075.

15. Cambien, F., O. Poirier, L. Lecerf, A. Evans, J.-P. Cambou, D. Arveiler, G. Luc, J.-M. Bard, L. Bara, S. Ricard, et al. 1992. Deletion polymorphism in the gene for angiotensin-converting enzyme is a potent risk factor for myocardial infarction. Nature (Lond.). 359:641-644.

16. Doria, A., J. H. Warram, and A. S. Krolewski. 1994. Genetic predisposition to diabetic nephropathy: evidence for a role of the angiotensin I-converting enzyme gene. Diabetes. 43:690-695.

17. Marre, M., P. Bernadet, Y. Gallois, F. Savagner, T.-T. Guyene, M. Hallab, F. Cambien, P. Passa, and F. Alhenc-Gelas. 1994. Relationships between angiotensin I converting enzyme gene polymorphism, plasma levels, and diabetic retinal and renal complications. Diabetes. 43:384-388.

18. Laragh, J. H. 1990. New angiotensin converting enzyme inhibitors. Their role in the management of hypertension. Am. J. Hypertens. 3:257-265.

19. Braunwald, E. 1991. ACE inhibitors: a cornerstone of the treatment of congestive heart failure. N. Engl. J. Med. 325:351-353.

20. Powell, J. S., J.-P. Clozel, R. K. M. Müller, H. Kuhn, F. Hefti, M. Hosang, and H. R. Baumgartner. 1989. Inhibitors of angiotensin converting enzyme prevent myointimal proliferation after vascular injury. Science (Wash. DC). 245:186188.

21. Yusuf, S., C. J. Pepine, C. Garces, H. Pouleur, D. Salem, J. Kostis, C. Bened, M. Bourassa, and B. Pitt. 1992. Effect of enalapril on myocardial infarction and unstable angina in patients with low ejection fractions. Lancet. 340:11731178.
22. Pfeffer, M. A., E. Braunwald, L. A. Moye, L. Basta, E. J. Brown, Jr., T. E. Cuddy, B. R. Davis, E. M. Geltman, S. Goldman, G. C. Flaker, et al. 1992. Effect of captopril on mortality and morbidity in patients with left ventricular dysfunction after myocardial infarction. N. Engl. J. Med. 327:669-677.

23. Lewis, E. J., L. G. Hunsicker, R. P. Bain, and R. D. Rohde. 1993. The effect of angiotensin-converting-enzyme inhibition on diabetic nephropathy. $N$. Engl. J. Med. 329:1456-1462.

24. Bell, L., and J. A. Madri. 1990. Influence of the angiotensin system on endothelial and smooth muscle cell migration. Am. J. Pathol. 137:7-12.

25. Bell, L., D. J. Luthringer, J. A. Madri, and S. L. Warren. 1992. Autocrine angiotensin system regulation of bovine aortic endothelial cell migration and plasminogen activator involves modulation of proto-oncogene $\mathrm{pp}^{\mathrm{c}} \mathrm{0}^{\mathrm{c}-\mathrm{src}}$ expression. J. Clin. Invest. 89:315-320.

26. Ridker, P. M., C. L. Gaboury, P. R. Conlin, E. W. Seeley, G. H. Williams, and D. E. Vaughan. 1993. Stimulation of plasminogen activator inhibitor in vivo by infusion of angiotensin II. Circulation. 87:1969-1973.

27. Liang, P., and A. B. Pardee. 1992. Differential display of eukaryotic messenger RNA by means of polymerase chain reaction. Science (Wash. DC). 257:967-971.

28. Nishio, Y., L. P. Aiello, and G. L. King. 1994. Glucose induced genes in bovine aortic smooth muscle cells identified by mRNA differential display. FASEB (Fed. Am. Soc. Exp. Biol.) J. 8:103-106.

29. Aiello, L. P., G. S. Robinson, Y.-W. Lin, Y. Nishio, and G. L. King Identification of multiple genes in bovine retinal pericytes altered by exposure to elevated levels of glucose using mRNA differential display. Proc. Natl. Acad. Sci. USA. 91:6231-6235.

30. Hachiya, H. L., S. Takayama, M. F. White, and G. L. King. 1987. Regulation of insulin receptor internalization in vascular endothelial cells by insulin and phorbol ester. J. Biol. Chem. 262:6417-6424.

31. King, G. L., A. D. Goodman, S. Buzney, A. Moses, and C. R. Khan. 1985. Receptors and growth promoting effects of insulin and insulin-like growth factors on cells from bovine retinal capillaries and aorta. J. Clin. Invest. 75:10281036.

32. Bruzdzinski, C. J., M. F. Riordan, E. C. Nordby, S. M. Suter, and T. D. Andgelehrter. 1990. Isolation and characterization of the rat plasminogen activator inhibitor-1 gene. J. Biol. Chem. 265:2078-2085.

33. Laborda, J. 1991. 36B4 cDNA used as an estradiol-independent mRNA control is the cDNA for human acidic ribosomal phosphoprotein PO. Nucleic Acids Res. 19:3998.

34. Niiya, K., T. Takeuchi, M. Kobayashi, I. Miyoshi, T. Hayashi, and N. Sakuragawa. 1991. Dexamethasone and phorbol ester, but not cytokines, increase the production of plasminogen activator inhibitor type-2 in the PL-21 human promyelocytic leukemia cell line. Thromb. Haemostasis. 66:232-238.

35. Cousin, E., R. L. Medcalf, G. E. Bergonzelli, and E. K. O. Kruithof. 1991. Regulatory elements involved in constitutive and phorbol ester-inducible expression of the plasminogen activator inhibitor type 2 gene promoter. Nucleic Acids Res. 19:3881-3886.

36. Schleuning, W.-D., R. L. Medcalf, C. Hession, R. Rothenbühler, A. Shaw, and E. K. O. Kruithof. 1987. Plasminogen activator inhibitor 2: regulation of gene transcription during phorbol ester-mediated differentiation of U-937 human histiocytic lymphoma cells. Mol. Cell. Biol. 7:4564-4567.

37. Timmermans, P. B. M. W. M., P. C. Wong, A. T. Chiu, W. F. Herblin, P. Benfield, D. J. Carini, R. J. Lee, R. R. Wexler, J. M. Saye, and R. D. Smith 1993. Angiotensin II receptors and angiotensin II receptor antagonists. Pharmacol. Rev. 45:205-251

38. Kruithof, E. K. O. 1988. Plasminogen activator inhibitors - a review. Enzyme (Basel). 40:113-121.

39. Ullian, M. E., and S. L. Linas. 1990. Angiotensin II surface receptors coupling to inositol triphosphate formation in vascular smooth muscle cells. $J$. Biol. Chem. 265:195-200.

40. Griendling, K. K., S. E. Rittenhouse, T. A. Brock, L. S. Ekstein, M. A Gimbrone, and R. W. Alexander. 1986. Sustained diacylglycerol formation from inositol phospholipids in angiotensin II-stimulated vascular smooth muscle cells. J. Biol. Chem. 261:5901-5906.

41. Ito, H., Y. Hirata, S. Adachi, M. Tanaka, M. Tsujino, A. Koike, A. Nogami, F. Marumo, and M. Hiroe. 1993. Endothelin-1 is an autocrine/paracrine factor in the mechanism of angiotensin II-induced hypertrophy in cultured rat cardiomyocytes. J. Clin. Invest. 92:398-403.

42. Toullec, D., P. Pianetti, H. Coste, P. Bellevergue, T. Grand-Perret, M. Ajakane, V. Baudet, P. Boissin, E. Boursier, F. Loriolle, et al. 1991. The bisindolylmaleimide GF 109203X is a potent and selective inhibitor of protein kinase C. J. Biol. Chem. 266:15771-15781.

43. Oliver, F. J., G. de la Rubia, E. P. Feener, M.-E. Lee, M. R. Loeken, T. Shiba, T. Quertermous, and G. L. King. 1991. Stimulation of endothelin-1 gene expression by insulin in endothelial cells. J. Biol. Chem. 266:23251-23256.

44. Hu, K.-Q., J. M. Backer, G. Sahagian, E. P. Feener, and G. L. King 1990. Modulation of the insulin growth factor II/mannose 6-phosphate receptor 
in microvessel endothelial cells by phorbol ester via protein kinase C. J. Biol. Chem. 265:13864-13870.

45. Force, T., J. M. Kyriakis, J. Avruch, and J. V. Bonventre. 1991. Endothelin, vasopressin, and angiotensin II enhance tyrosine phosphorylation by protein kinase $\mathrm{C}$-dependent and -independent pathways in glomerular mesangial cells. J. Biol. Chem. 266:6650-6656.

46. Yang, S.-G., M. Saifeddine, A. Laniyonu, and M. D. Hollenberg. 1993. Distinct signal transduction pathways for angiotensin-II in guinea pig gastric smooth muscle: differential blockade by indomethacin and tyrosine kinase inhibitors. J. Pharmacol. Exp. Ther. 264:958-966.

47. Akiyama, T., J. Ishida, S. Nakagawa, H. Ogawara, S. Watanabe, N. Itoh, M. Shibuya, and Y. Fukami. 1987. Genistein, a specific inhibitor of tyrosinespecific protein kinases. J. Biol. Chem. 262:5592-5595.

48. Mawatari, M., K. Okamura, T. Matsuda, R. Hamanaka, H. Mizoguchi, K. Higashio, K. Kohno, and M. Kuwano. 1991. Tumor necrosis factor and epidermal growth factor modulate migration of human microvascular endothelial cells and production of tissue-type plasminogen activator and its inhibitor. Exp. Cell Res. 192:574-580.

49. Pepper, M. S., N. Ferrara, L. Orci, and R. Montesano. 1991. Vascular endothelial cell growth factor (VEGF) induces plasminogen activators and plasminogen activator inhibitor-1 in microvessel endothelial cells. Biochem. Biophys. Res. Commun. 165:1198-1206.
50. Reilly, C. F., and R. C. McFall. 1991. Platelet-derived growth factor and transforming growth factor-b regulate plasminogen activator inhibitor-1 synthesis in vascular smooth muscle cells. J. Biol. Chem. 266:9419-9427.

51. Schunkert, H., J. R. Ingelfinger, A. T. Hirsh, S.-S. Tang, S. E. Litwin, C. E. Talsness, and V. J. Dzau. 1992. Evidence for tissue-specific activation of renal angiotensinogen mRNA expression in chronic stable experimental heart failure. J. Clin. Invest. 90:1523-1529.

52. Vassalli, J.-D., A.-P. Sappino, and D. Belin. 1991. The plasminogen activator/plasmin system. J. Clin. Invest. 88:1067-1072.

53. Krishnamurti, C., and B. M. Alving. 1992. Plasminogen activator inhibitor type 1: biochemistry and evidence for modulation of fibrinolysis in vivo. Semin. Thromb. Heamostasis. 18:67-80.

54. Erickson, L. A., G. J. Fici, J. E. Lund, T. P. Boyle, H. G. Polites, and K. R. Marotti. 1990. Development of venous occlusions in mice transgenic for the plasminogen activator inhibitor-1 gene. Nature (Lond.). 346:74-76.

55. Carmeliet, P., J. M. Stassen, L. Schoonjans, B. Ream, J. J. van den Oord, M. De Mol, R. C. Mulligan, and D. Collen. 1993. Plasminogen Activator Inhibitor1 Gene-deficient Mice. II. Effects on Hemostasis, Thrombosis, and Thrombolysis. J. Clin. Invest. 92:2756-2760.

56. Simonson, M. S., and W. H. Herman. 1993. Protein kinase C and protein tyrosine kinase activity contribute to mitogenic signaling by endothelin-1. J. Biol. Chem. 268:9347-9357. 